\title{
The Intellectuality of Al-Dihlawi: A Review on His Contribution in Science of Prophetic Tradition
}

\author{
Mohd Arif Nazri ${ }^{1}$ \\ Lutpi Mustafa1 \\ Fadlan Mohd Othman ${ }^{1}$ \\ Ahamad Asmadi Sakat ${ }^{1}$ \\ Abur Hamdi Usman ${ }^{2}$ \\ Mohd Fauzi Mohd Amin ${ }^{3}$ \\ 1 Faculty of Islamic Studies, The National University of Malaysia, Malaysia \\ 2 International Islamic University College Selangor (KUIS), Malaysia \\ Corresponding Author Email: aburhamdi@kuis.edu.my \\ ${ }^{3}$ Faculty of Quranic and Sunnah Studies, Islamic Science University of Malaysia, Malaysia
}

Doi:10.5901/mjss.2015.v6n5s1p302

\begin{abstract}
The greatest scholar of 18th century India better known as Shah Wali Allah al-Dihlawi who wrote a number of works, especially on the science of prophetic tradition (hadith). He was a scholar who contributed many ideas to express the unification of Muslims in terms of comprehension and appreciation. Undeniably, he has strived to establish Islam to the society by recognizing the Qur'an and Sunna as the basis of reformation. Therefore, this study attempts to analyse the intellectuality of alDihlawi as a famous hadith scholar and his contribution towards the appreciation of Sunna of the prophet. By applying content analysis method as the study design by focusing on his great work, Hujjat al-Baligha, the study found that the transformation carried out by al-Dihlawi then he was considered a moderate figure who tried to balance between demands worldly and hereafter goals to the community. His efforts toward the unity of umma were considered positively when succeed to quell internal dissent and ideology differences between the fighism and Sufism, and also between the rationalists (ahl al-Ra'y) and the traditionalists (ahl al-Hadith).
\end{abstract}

Keywords: Hadith; Al-Dihlawi; Intellectual; Hujjat al-Baligha, Sufism

\section{Shah Wali Allah Al-Dihlawi (1702-1762): A Biographical Highlight}

Shah Wali Allah was born on the $4^{\text {th }}$ of Shawwal, 1114/1702 in Pulth, in district Muzaffargarh, Delhi, India, (Jalbani, 1967). He has been dubbed as the Qutb al-Din which means religious center, while the word 'Shah' placed in front of his name comes from the Persian word which means king, and this title is only awarded to scholars and Sheikh Sufi (AlDihlawi: 2005: 12-13). He is also known as the Wali Allah as his profound understanding of the religion and from the point of use of this word is usually given to Sufi religious leaders and have miracles. His descendants came from Umar alKhattab the second Caliph of Islam. The word of al-Dihlawi is derived from the word New Delhi, which is the name of his hometown (Mahfudz, 2010).

al-Dihlawi is an important Muslim reformer in India. After studying in Delhi, al-Dihlawi spent some time in mecca, which was an important meeting place for Muslims from all corners of the world. When he returned to India, he called for the reform of a number of areas of Islamic belief and practice, suggesting that of the traditional four sources of Islamic law only two, the Quran and the hadith had ongoing validity, and that these needed creative interpretation (ijtihad) in order to make their message applicable in the Indian context. He therefore translated the Quran into Persian, the cultured language of Indian Muslims, and his sons translated it into Urdu. He also suggested that the hadith needed careful review, in order to clarify which sections were unreliable, this work thus serving as an early example of hadith criticism. And he also argued that the different schools of sharia law were no longer valid, and that was needed was a return to the situation before their emergence, so that there could be one school for all Muslims (Goddard, 2010). 
He was the most prominent Mulim intellectual of eighteenth-century India and a prolific writer on a wide range of Islamic topic in Arabic and Persian. Al-Dihlawi's formal name was Qutb al-Din Ahmad Abu al-Fayyad. Biographical material and anecdotes concerning his life and family may be found in his brief Persian autobiography, al-Juz' al-latif fi tarjamat al-'abd al-da'if, and his Persian work Anfas al-'Arifin. Some additional material on his life appears in the hagiographic account al-qawl al-jali, written by his close disciple Muhammad Ashiq (d. 1773). Al-Dihlawi's father and spiritual guide, Shah 'Abd al-Rahim (d. 1719), was a well-known scholar in charge of his own madrasa in Delhi and also a practicing mystic. His father devoted considerable attention to the education of his precocious son: besides religious subjects, his studies included astronomy, mathematics, Arabic and Persian language and grammar, and medical science, from which many concepts and theories influence his works.

For twelve years after his father's death al-Dihlawi taught and studied the religious sciences and continued in meditative discipline. Then in 1731, he left India to Hejaz for some fourteen months. This stay in the Hejaz was an important formative influence on his thought and subsequent life. There he studied hadith, figh, and Sufism with various eminent teachers. These teachers in Mecca exposed al-Dihlawi to the trend of increased cosmopolitanism in hadith scholarship that began to emerge there in the eighteenth century. While in the holy cities, al-Dihlawi developed a particular respect for Malik's work, the Muwatta', on which he later wrote two commentaries, Musawwa (Arabic) and Musaffa (Persian) (Hermansen, 2009).

His faith thought more likely to sect Ahl al-Sunnah wa al-Jama'ah. In Sufism, he was a member of alNaqshabandiyah order since at the age of fifteen. From there, the daily routine of his life mostly spent on training and practices of Sufism (Fuad Said, 1999). At the same stage, al-Dihlawi graduated his education in the field of religion and his ability was recognized by his father caused him to teach the people in religious studies (Mahfudz, 2010). In figh, alDihlawi tended to Hanafi, but he had great respect for Imam al-Shafie. He also greatly admired Imam Malik and put alMuwatta inline with Sahih Bukhari and Sahih Muslim.

Al-Dihlawi intellectual journey towards the uplift of science was divided into three stages, namely: (i) memorizing the Qur'an at the age of seven. (ii) Studying religious sciences with his father, such as linguistics, Qur'anic exegesis, hadith, law, mysticism, faith, medical, philosophy, social sciences and mathematics at the age of 15. And (iii) pursuit of knowledge to eminent scholars during his journey to Hejaz in 1731 (Al-Dihlawi, 2005). Al-Dihlawi's brand of Islamic reconstruction and reform radiated over a large part of India, through his pupils and sons, especially his eldest son, Shah 'Abd al-'Aziz al-Dihlawi (Rahman, 1968). He died on August 20, 1762 at the age of 62 years in his birthplace and buried in the side of his father (Nasution, 1993).

\section{The Mastery of Al-Dihlawi in Religious Sciences}

Al-Dihlawi's writing career began in earnest on his return from pilgrimage. His most important and influential work, Hujjat Allah al-Balighah (in Arabic), in which he aimed to restore the Islamic sciences through hadith studies, was composed sometime during the decade after his return. This is the most readily available and best-known of his works; even today it is considered important by Islamic reformers, whether Islamists or modernists, and it is studied in the Arab Middle East and Southeast Asia as well as in Muslim South Asia (Hermansen, 2009).

Indeed, al-Dihlawi's intellectual elements could be seen in various scientific fields such as linguistics, Quranic exegesis, Hadith studies, Islamic law, the rule of jurisprudence, morality, etc. He was able to master the Arabic and Persian well, among his works are written in Persian al-Hummi'at and Surur al-Mahzun (Al-Dihlawi, 2005).

In the field of Qur'anic studies, al-Dihlawi drew a good input as to pave the way in highlighting in Qur'anic interpretation methods, especially the methods of translation and exegesis. Although he was not regarded as a figure in line with others commentators, but his works about the Qur'an were enough to prove that he was an intellectual in the field of Qur'anic sciences. Among his writings to this field, such as Fath al-Rahman fi Tarjamah al-Quran and Risalah Nafisah (in Persian). Moreover, al-Zahrawain, al-Fawz al-Kabir and al-Fath al-Munir (in Arabic). He was also mastering the Islamic jurisprudence that emphasize of the four schools and by researching the prophetic traditions with producing laws which led to the Tariq al-Fuqaha al-Muhaddisin (the way of jurists and hadith scholars) (Al-Dihlawi, 2005). From here, he has made a description of the different opinions of scholars with described and explained a range of views of them, then analyzed and gave some comments as conclusion.

Al-Dihlawi's intellectuality prospect was invaluable and not just covered the religious studies solely. Due to the trust and responsibility of academic values, he felt the need to comment on issues related to civilizations, community social, political and economic, in which these elements relate to each other towards the construction of a society universally and comprehensively. Apparently, he able to dominate these elements well and debated the theories proposed in a logical and sensible. Thus it was not surprising, the theories thereof were preeminent and could be adopted until today. His 
thoughts were quite forward beyond the boundaries of life and the elapsed time. This was evident when he proved the theory of human civilization which considered in terms of their role in improving quality of life. He agreed that the natural of human beings are social creatures who need the co-operation between each other. Hence, Chamid (2010) pointed out that Islam prohibits activities that could damage a relationship and a spirit of these, such as gambling and interest practices. Both of these practices may lead to unfairly and exploitatively transaction that can create tension in the society.

Al-Dihlawi (2005) sparked his economic theory in Fan al-Mu'amalat that consider economic prosperity was indispensable for social life either. In this context, he commented that people need each other in the course of the process to produce a good product in their lives. Therefore, good social relations and strong economic systems are interrelated which involve political stability in a country.

\section{Al-Dihlawi's Dominance in Hadith: It's a Fact or Fake?}

Al-Dihlawi's thought in hadith talks about embodiment of the Prophet as a messenger who delivered the message to Muslims. This was a responsibility that needs to be perfected which became the official duties of him who has been sent. In fact, Brown (1996) stressed on neither the ahl al-ra'y (rationalists) nor ahl al-kalam (theologians) rejected the authority of the prophet in theory. They did, however, question whether, as the traditionists held, hadiths report were the best representation of the authority. What gave force to these debate was the fact that each of these groups believed itself to be acting on the legacy of the prophet; they were not fighting over whether to follow the prophet, but rather to over how to follow him.

It seems important to note here that neither all practices nor actions of the Prophet could be followed by his umma due to there are things just designated to him alone. This reality needs to be examined and refined to understand the position of the Prophet in various positions and functions as a role model in acts of worship. This fact is instructive to understand when the activities and actions that should be associated with his role (Masfufah, 2008). Therefore, implementing the hadith according to al-Dihlawi shown from the angle of the role played by the Prophet as a messenger of Allah. This role hence would establish rules and regulations known as kanun al-Tasyri'iyah (canon of legislation).

From this point, various theories and views arisen on how the means or method to follow the sunna in Muslims lives. Undeniably, al-Dihlawi regarded as a famous figure have narrated the chain of narrators in his hadith methodology which is equivalent to Abd Allah ibn Mubarak, al-Shafi'i, the disciples of al-Bukhari, al-Dhahabi, Ibn Hajar al-Asqalani, alHakim, etc. (Abu Hassan, 2004). His real mastery of Hadith, when he was in Hejaz, he studied Hadith, Jurisprudence and mysticism with several eminent scholars (Nasution, 1992). They introduce new knowledge about the philosophy of Hadith to al-Dihlawi who appeared there in the 18th century from West Africa, Syria and India (Mahfouz, 2010).

\section{Al-Dihlawi as a Continuity of Hadith Science}

Al-Dihlawi a member of an old scholarly family of Delhi which has left many scholarly works on Islam, both in Persian and Arabic languages, attempted to redress the balance of power in favour of Islam in India (Khan, 1981). The persona of alDihlawi in Hadith sciences was undisputedly. He was a rope connector and became prime mover to marketing his thought of hadith among the generations before him and after. From the concept of Hadith, his thought was similar with another hadith scholars. However, the opinions and views which inspired by him in the form of thought were different. The uniqueness of al-Dihlawi's thought could be seen from the point of Hadith discipline itself on the concept of selecting a hadith. This discipline interprets the elements of necessarily or unnecessarily in choosing a hadith, which there is no connection with the the issue of faith, acts of worship, Islamic jurisprudence, etc. Indirectly, his thoughts intended to open the doors of ijtihad in religious matters and develop this reality towards the other constituents.

Needs to be said, the emergence of the study of Hadith in India is in line with the process of Islamization, although this is still a subject of debate among scholars, such as Bruce Lawrance, RM Eaton, Peter Hardy, MA Rahim, K. Fazl-i Rabbi and Rafiuddin Ahmad. In the early stages, the phenomenon of the presence of Islam in India 'still raw' which appeared in the middle of Indian Hindu. Certainly, the practice of syncretism among the new converts to Islam can not be avoided. Seeing this occurs, al-Dihlawi appeared to repair this situation so that people return to the bosom of religion normally (Khan, 1991).

The development of hadith sciences in India began to enter a new phase when the rise of al-Dihlawi which is regarded as a database of successful of Indian scholars in seizing the high dignity in the science of hadith from the thirteenth century ago until now. He spread the new thinking in the science of Hadith to open the mysteries of this science and to establish the concept of contemporary ijtihadiyah, where the debate is not confined to the issue of the chain of narrators and text, even on istinbat in Islamic law. Thus, al-Dihlawi's mastery of hadith not only focus on merely traditions 
thought, but he used this platform as a stage for development and spread of religious teachings. Among his works are alMustafa Sharh al-Muwatta', al-Maswa Sharh al-Muwatha' written in Arabic with describing sectarian differences and explanation of strange words, Tarajim Abwab al-Bukhari, al-Nawadir min Ahadith Sayyid al-Awail wa al-Akhirin, Arbain, al-Dar al-Thamin fi Mubasyarat al-Nabi al-amin, al-Irshad ila Muhimmat al-Isnad, Insan al-'Ain fi Mashayikh al-Haramain written in French (Al-Dihlawi, 2005). Nevertheless, what is important here, al-Dihlawi as connector figure in pioneering his hadith thought that has been growing rapidly worldwide, including the Malayan Archipelago especially in Kelantan and Terengganu (Mohd. Tap, 2009).

\section{Hujjat Allah al-Balighah: The Classification of Hadith in the Eye of al-Dihlawi}

The book, Hujjat Allah al-Baligha, the magnum opus, is the unique production of al-Dihlawi. He has goven therein an exhaustive account of the science of hadith and has unravelled the secrets underlying it. The book is so informative on this point that it won't be an exaggeration to call it a work of the hadith (Jalbani, 1967). The definition of hadith according to al-Dihlawi was similar with the views of other scholars which describe on the relation elements of speech, acts and affirmation of the Prophet as productivity (al-Maliki, 1990). However, two important aspects outlined by al-Dihlawi through the book Hujjat Allah al-Baligha were not found in other books which is seen on the classification of tabligh (presentation) aspect. He categorizes the hadith into two parts, namely Hadith tabligh al-Risalah and Hadith tabligh Ghair al-Risalah.

According to al-Dihlawi (2005) the hadith tabligh al-risala means the hadith narrated by the Prophet in his condition as a messenger of God, such as the hadiths talk about the unseen, the provisions of the law of God and Muslims religious duties. Then, Prophet position as a messenger is obliged to be obeyed. Therfore, this matter has been discussed in sura al-Hashr (The Exile), verse 7 while Allah said:

...And whatever the Messenger has given you - take; and what he has forbidden you - refrain from...

According to al-Dihlawi (2005) in this section including the sciences that are related to the affairs of Hereafter and the miracles that can not be described and conceived by human intellect, scinces which are relate to the rule of law, the issues in worship of God, and human relations which all these are based on what was revealed by God and the sciences of hikam mursalah (the wisdom of benefits) and maslahah mutlak (consideration of public interest). Among of these are the knowledge about fada'il al-a'mal (the virtues of deeds) and manaqib al-'ummal (qualities and characteristics of the doers), where part of both notions based on revelation and ijtihad (exerting oneself to the utmost limit).

Whereas the hadith through Tabligh Ghair al-Risalah is the hadith narrated by the Prophet as an ordinary man not as messenger. This means his sunna does not compulsory to be obeyed. Al-Dihlawi submitted this view with two of Prophet's words as follows:

I am a human being, so when I command you about a thing pertaining to religion, do accept it, and when I command you about a thing out of my personal opinion, keep it in mind that I am a human being. 'Ikrima reported that he said something like this. ${ }^{1}$

and;

for it was just a personal opinion of mine, and do not go after my personal opinion; but when I say to you anything on behalf of Allah, then do accept it, for I do not attribute lie to Allah, the Exalted and Glorious. 2

According to al-Dihlawi (2005) the sciences that are included in this category are related to the hadith of medical, civilization, any knowledges gained from experiences, and not related to religious matters, various topics of discussion were uttered by the Prophet in front of the public, and all matters relating to wisdom which are particular (juz'iyah).

This study found that the concept of hadith risalah dan ghair al-risalah has been applied and shared by previous scholars after that, among them Saltut (1966) who argued from the point of position and function of the hadith and sunna. The same arguments with al-Dihlawi, Saltut divided the hadith into two categories, sunna al-tashriilyah (legislative tradition) and sunna ghair al-tashritiyah (non-legislative tradition). The explanation seems to be similar also voiced by alShawkani (2000) in his book Irshad al-Fuhul and al-Namri (1985) in al-ijtihad. Both of them are identical with the alDihlawi's ideas, even from the point of terminology was different, but in terms of reviews and commentary appeared the

\footnotetext{
1 See Muslim. (2005). al-Jāmic al-Șahịh, chap. Wujub imtithal ma qalahu shar'an, vol. 4, p. 1835, Hadis number 2362.
}

2 See Muslim. (2005). al-Jāmic al-Șahịḥ, chap. Wujub imtithal ma qalahu shar'an, vol. 4, p. 1835, Hadis number 2361. 
same reality.

In this issue, al-Dihlawi's reflection tends to choose which is more permanent, and which are changed from religious teachings in the text of the hadith. Such selection are indeed very effective, especially when dealing with situation and condition, where Muslims will focus more on the aspects which remained compared with that unchanged aspect. However, al-Dihlawi's bipolar-concept of this was highly subjective term due to it depends on the assessment of an individual (Munawir, 2009). From this perspective, the classification of the hadith according to al-Dihlawi due to the position of the Prophet neither as messenger of gor nor human beings as a basis of thought. The needed criteria of the hadith in his discourse ha given great contributions in the ability to understand the hadith. However, this classification must be seen to other factors such as quality of the hadith and its asbab al-wurud (the circumstances of occurrence), due to the application of the new classification could be carried out after exceeded that level (Masfufah, 2008).

\section{The Spiritual Hadith: An Implementation of al-Dihlawi's Experience}

Al-Dihlawi was a hadith expert and his intellectuality was not only a curtain of Islamic civilization in India even across the world undoubtedly. His works are translated into many languages and became a references for several generations until now. The values of his thoughts had succeeded in opening the eyes of Islamic scholars to develop a structured mind as well as expanding its own scientific civilization. His prowess inspired to create differences from a movement thought which was permeated with the spirit of rabbaniyah (relationship with God). This relation led to his being able to go a step further to build uniqueness thought.

He studied in Medina for 14 years and gained recognition in Hadith. While there, he gained a lot of mystical experiences have a huge impact on himself. His mystical experience has been fully utilized to produce hadith works which are narrated trough a vision. He accommodated those hadiths in his book al-Durr al-Thamin fi Mubasharat al-Nabi al-Amin (Al-Dihlawi, 1890). Although the hadith narrated by mystics was beyond the methodology of hadith science, but this work clearly shows his personal relationship with Prophet as something really abstract and amazing. Thus, he is a prominent scholar who can be regarded as sophisticated about it for having the unique position thereon. Nevertheless, he noted that the hadiths in this book were considered a private collection of his scholarly studies. From here, it shown his seriousness and mastery in hadith science. Accordingly, he considered the mastery in hadith was not only recorded on sheets of paper purely, but it was impressed by the spiritual which lay servitude values as bound in mastering of this science.

Al-Dihlawi's dimension of thought is very creative and also visible through this work, he tried to combine the elements of hadith science and sufism which are rarely done by other scholars. In other words, by hadith, he able to develop the concept of Sufism through Al-Naqshbandi order to society as a practice of life. With his position as the the hadith experts and respected scholars, this approach was very impressed and able to restore relations between conflicting sects at that time. Al-Dihlawi's scientific reform broke the monopoly of the traditional thinking which considered rigid that refuses the concept of ijtihad. Hence, al-Dihlawi's spiritual approach can be witnessed from the hadith below:

The Prophet hinted spiritually that addressed to al-faqir (al-Dihlawi) that what was required by al-Haq (Allah) on you is God Almighty who will gather the blessing unity of umma because of you.

This spiritual tradition shows al-Dihlawi's dream to see the Prophet which pays tribute to him to unite the umma. This is a mystical sign that reflects the Prophet's instruction to al-Dihlawi that he is the most qualified person to assume responsibility to develop Islamic teachings. Thus, this spiritual experience recognizes that the order brought in by alDihlawi meets the requirements of Shariah aspirations. The issue has been discussed in other spiritual traditions which tells same case:

I have asked the Prophet regarding the sects, which one of sufi order is more important on his side to be held and favored? Then overflowed on my heart from him s.a.w. that all sects and orders are the same, no more of one over the others.

This spiritual tradition means the orders which meet Islamic law and hold fast to the Qur'an and Sunna are similar and could be followed. Al-Dihlawi's approach to compromise the disciplines of Hadith and Sufism can be seen through a piece of his another spiritual experience as follow:

My father told me that he saw the Prophet in the dream and recited the remembrance of al-nafy and al-ithbat (La ilaha illa Allah) as according to the Sufi orders to him, and my father pledged allegiance to me as the Prophet did to him, and 


\section{he recited to me as the Prophet did.}

From this hadith, al-Dihlawi put elements of Sufism as a very noble aspiration to be stepped in daily life, and shows real connection to the God which is rooted in the word of unification. The implementation of spiritual hadith by al-Dihlawi proves his an intellectual thought beyond ordinary levels of knowledge. Thus, in the eye of Sufism al-Dihlawi's the spiritual experience was reasonable. Due to among the mystics, they consider the Shaykh as a guider and has a close connection with the divinity of God. Hence, they need to transform their relationship with the Shaykh in their internal bond (rabita) (Napiah, 2005).

\section{Al-Dihlawi's Approach of Religious Reformation: An Introduction}

Al-Dihlawi sought the reform of Sufism, but his tolerance only extended to Muslimscand his concern was with Muslim identity and survival as much as it was for Sirhindi. Al-Dihlawi was an advocate of Islamic reform and the establishment of a traditional Islamic state, not the watering down of Islam within a pluralistic society. From this perspective, al-Dihlawi undoubtedly considered Islam to be the superior religion to that of its nin-Muslim counterparts. Al-Dihlawi's teachings resulted in a revival of Islamic thought in India (Jackson, 2011).

The mastery of al-Dihlawi in various fields of science have created apparent phenomenon towards shaping the umma perception. His views on the concept of ijtihad gives opportunities to dignify the integrity of religious values and would covers areas of ignorance indirectly. He tried to establish a new idea based on Quran and sunna known as tariq alfuqaha' al-muhaddithin (The jurists and Hadith scholars approach) which aims to eliminate extreme forms of rigidity thought. He emphasized the study of Islamic jurisprudence comparison (al-figh al-muqaranah) between the popular four schools. He also collected the views and opinions of different scholars, and ecplained the differences with a good description by prufication (al-tarjih) method (Al-Dihlawi, 2005).

Al-Dihlawi's approach on Tariq al-Fuqahat al-Muhaddithin seen at an appropriate time, because of there is a polemical fierce among the group of ahl al-hadith and ahl al-ra'yy which showing a bit critical atmosphere (Rachman, 1995). Initially, the climatic thought between them was very conducive and competitive, they presented religious issues in interesting and creative ways, thereby forming dozens of law with various views. However, this situation took short-lived when the debate turned to enforce each group establishment and not to uphold the interests of religion. Some of them using religious platforms to produce a wide range of law just to defend their group's integrity. These are the stormy days of religious decadence when people were divided in sections and sub-sections, each one happy in his own set of beliefs without any regard as to what was true and false (Jalbani, 1967). And the main source of discrepancy between both stems from the existence of hadith transmission paradigm into the texts of hadith (Ham, 2000). Due to the hadith is considered as a source of information which includes dynamic exemplary of the Prophet and should be followed after transmitted in a verbal discourse, through the narration of the companions to the current generation or after them (Hidayat, 1996). Ahl al-Hadith understand the hadith textually, while ahl al-ra'yy tend to contextually (Munawir, 2009). In general, the textual and contextual comprehension actually had been implemented by the companions during the life of the Prophet. But these perceptions became an issue of their debate and far from being resolved (Shihab, 1996).

Thus, the core concept of al-Dihlawi was considered as a solution between the two groups because of its role in binding the debate by applying the hadith texts. He seems to provide a shortcut to shape umma by revealing the ijtihad curtain in order to establish his thought based on figh al-hadith (jurisprudence of hadith). Indirectly, this would deny any perspectives which is sourced on logic and became mange in religious debates. This al-Dihlawi's model of thought was also regarded as transformation of law in coloring religious discourse into conclusive word in any issues raised by the public (Nasution, 1997). Finally, his introduction of hadith al-Risalah and Ghair al-Risalah was to tie variety reasons why the Shari'ah rules arised and to find the correlation between the substances of law (Maqasid) with the Shari'ah (AlDihlawi, 2005). In other words, it was introduced al-Fuqahat al-Muhaddithin which applies the elements of jurisprudence and hadith in one brand, namely maqasid al-Shari'a (the ultimate objectives of Islamic law).

\section{Conclusion}

Al-Dihlawi represents an expert of hadith who always proceed on the right way to explain the the secrets of Islamic law based on the Quran and hadith teachings, and highlighted thereof the true meanings wisely. Although al-Dihlawi dominated many areas of science, but he was known as a prominent hadith and has intellectuallity in this field. His dominance in hadith has been inspire him to master all fields, whether secular or religious of sciences.

Al-Dihlawi able to create fresh ideas to solve community problems and put the Quran and hadith as roots. $\mathrm{He}$ 
blended his hadith's thought with jurisprudence and Sufism to harmonize humanity apprehension. His scholarship on religious studies was inspired by his asceticism as well as his religious family background. Indeed his ideas need to be inherited and expanded to the new generation, especially on his famous hadith work. Hujjat Allah al-Baligha. He considered a precursor in the scrolls of history of Hadith in India and produced many scholars in this field after his glory era. His greatness in Hadith proven when he founded the tariq al-Fuqaha al-Muhaddithin which contains patterns of jurisprudence and hadith thoughts as a platform in ijtihad issues and generate Islamic laws.

\section{References}

Abu Hassan, M. Z. (2004). Faktor-Faktor yang Mempengaruhi Pembelajaran Secara Tradisional: Satu Kajian di Madrasah Al-Yamani [The factors which influenced traditionally learning: A Study in Madrasah Al-Yamani]. Unpublished thesis. Malaysia: Universiti Teknologi Malaysia.

Brown, W. D. (1996). Rethinking Tradition in Modern Islamic Thought. Cambridge: Cambridge University Press.

Chamid, C. (2010). Jejak Langkah Sejarah Pemikiran Ekonomi Islam [The footsteps of Islamic history of economic thought]. Yogyakarta: Pustaka Belajar.

Al-Dihlawi, S. W. A. (2005). Hujjat Allah al-Balighah [The conclusive argument from God). Beirut: Dar al-Jail.

Al-Dihlawi, S. W. A. (1890). Al-Durr al-Thamin fi Mubasyarat al-Nabi al-Amin. Riyadh: Maktabah al-Malik Fahd al-Wataniyah.

Goddard, H. (2010). Shah Waliullah. In Netton, I. R. (Ed.), Encyclopedia of Islamic Civilization and Religion. New York: Routledge, p. 591.

Ham, M. 2000. Evolusi Konsep Sunah Implikasinya Pada Perkembangan Hukum Islam [The evolution of Sunna concept: Its implication in the development of Islamic law]. Semarang: Aneka IImu.

Hermansen, M. K. (2009). Wali Allah, Shah. In Esposito, J. L. (Ed.). The Oxford Encyclopedia of the Islamic World. Vol. 5. New York: Oxford, pp. 517-519.

Hidayat, K. (1996). Memahami Bahasa Agama: Sebuah Kajian Hermeneutis. [Understanding the Language of Religion: A Hermeneutical Review]. Jakarta: Paramadina.

Jackson, R. (2011). Mawlana Mawdudi and Political Islam: Authority and the Islamic State. New York: Routledge.

Jalbani, G. N. (1967). Teachings of Shah Waliyullah of Delhi. Pakistan: SH. Muhammad Ashraf Press.

Khan, M. I. (2011). Studying Conversion to Islam in Indian History - A Case Study. In. Journal Institute of Muslim Minority Affairs, vol. 12, issue 1, p. 149-157.

Khan, R. N. (1981). Modern Muslim Thinkers in Indian Subcontinent. In Islam, Philosophy and Science, Paris: The UNESCO Press, pp. 99-132.

Mahfudz, A. (2010). Pembaharuan Hukum Islam: Telaah Manhaj ljtihad Shah Wali Allah al-Dihlawi [Renewal of Islamic Law: The Study of ljtihad Shah Wali Allah al-Dihlawi Methodology]. Yogyakarta: Penerbit Teras.

Mahmud Saltut. (1966). Al-Islam Aqĩdah wa Syari'ah. Beirut: Dar al-Qalam.

Al-Maliki, M. A. (1990). Al-Manhal al-Latif fi Usul al-Hadith al-Sharif. Jeddah: Sahar al-Mamlakah al-Arabiyah.

Masfufah, S. (2008). Klasifikasi Sunnah Menurut Pemikiran Shah Wali Allah Al-Dihlawi [the classification of Sunnah according to Shah Wali Allah Al-Dihlawi thought]. Unpublished thesis. Yogyakarta: Islamic State University of Sunan Kalijaga,

Mohd. Tap, M. N. (2009). Mencarik llusi Menggapai Realiti: Wacana Tasawuf, Tarekat \& Pemikiran Kalam Imam Ahmad al-Sirhindi [Shredding the illusions and reaching the reality: Discourse of Sufism, orders and Imam Ahmad al-Sirhindi Thought]. Kajang: Akademi Kajian Ketamadunan.

Munawir. (2009). Tipologi Pembagian Hadis Risalah dan Gair Risalah: Studi Pemikiran Hadis al-Dahlawi [The typology classification of Hadis Risalah and Gair Risalah: A Study of al- Dahlawi's Hadith Thought]. Journal of Studi IImu-IImu al-Qur'an dan Hadis, vol. 10, no. 1, pp. 111-136.

Muslim, A. H. (2005). al-Jāmic al-Ṣahị̄ḥ. Vol. 4. Beirut: Dār al-Jīl.

Al-Namri, A. M. (1985). Al-ljtihad. Cairo: Dar al-Kutub al-Islamiyyah.

Napiah, O. (2005). Keberkesanan Dalam IImu Tasawuf [The effectiveness of Sufism]. Johor: Universiti Teknologi Malaysia.

Nasution, H. (1992). Pembaruan Dalam Islam: Sejarah Pemikiran dan Gerakan [Islamic reform: The history of thought and movement]. Jakarta: Bulan Bintang.

Nasution, H. (1993). Ensiklopedia Islam [Encyclopedia of Islam]. Jakarta: Andi Utama.

Nasution, K. (1997). Shah Waliyullah al-Dahlawi dan Kecemerlangan Pemikirannya [Shah Waliyullah al-Dahlawi and His Thought]. In Journal Penelitian Agama, no. 15, pp. 36-44.

Rachman, B. M. (1995). Konstekstualisasi Doktrin Islam Dalam Sejarah [The contextuality of Islamic Doctrine in History]. Jakarta: Yayasan Paramadina.

Rahman, F. Islam. (1968). New York: Anchor Books.

Said, F. (1999). Hakikat Tarikat Naqsyabandiyah [The fact of Naqsyabandiyah order). Jakarta: Al-Husna Zikra.

Al-Shawkani, M. A. (2000). Irshad al-Fuhul ila Tahqiq al-Haq min 'Ilm al-Usul. Beirut: Mu'assasah Al-Rayyan.

Shihab, M. Q. (1996). Hubungan Hadith dan al-Qur'an: Tinjauan Segi Fungsi dan Makna [Correlation between Hadith and Qur'an: A review of its function and meaning aspects]. In llyas, Y. (Ed), Pengembangan Pemikiran Terhadap Hadits. Yogyakarta: LPPI UNMUH. 